Biosystems Engineering (2005) 91 (2), 127-137

Available online at www.sciencedirect.com

doi:10.1016/j.biosystemseng.2005.03.006

IT-Information Technology and the Human Interface

Science

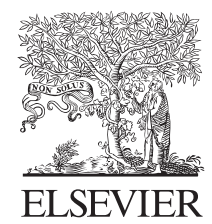

\title{
Organic Farming Scenarios: Operational Analysis and Costs of implementing Innovative Technologies
}

\author{
Claus G. Sørensen ${ }^{1}$; Niels A. Madsen²; Brian H. Jacobsen ${ }^{2}$ \\ ${ }^{1}$ Department of Agricultural Engineering, Danish Institute of Agricultural Sciences, Research Centre Bygholm, Schüttesvej 17, 8700 Horsens, \\ Denmark; e-mail of corresponding author: Claus.Soerensen@agrsci.dk \\ ${ }^{2}$ Danish Research Institute of Food Economics, Rolighedsvej 25, 1958 Frederiksberg C, Denmark; e-mail: brian@foi.dk
}

(Received 21 May 2004; accepted in revised form 14 March 2005; published online 10 May 2005)

The objective of this study has been to design a number of farm scenarios representing future plausible and internally consistent organic farming enterprises based on milk, pig, and plant production and use these farm scenarios as the basis for the generation of generalised knowledge on labour and machinery input and costs. Also, an impact analysis and feasibility study of introducing innovative technologies into the organic production system has been invoked.

The labour demand for the production farms ranged from $6 \cdot 1$ to $25.3 \mathrm{~h} \mathrm{ha}^{-1}$ and from 19.4 to $39.6 \mathrm{~h} \mathrm{\textrm {LU } ^ { - 1 }}$ ( $\mathrm{LU}$ is livestock units) for work in the animal houses. Model validation results showed that farm managerial tasks amount to $14-19 \%$ of the total labour requirement. The impact of introducing new technologies and work methods related to organic farming was evaluated using two innovative examples of weed control: a weeding robot and an integrated system for band steaming. While these technologies increased the capital investment required, the labour demand was reduced by $83-85 \%$ in sugar beet and $60 \%$ in carrots, which would improve profitability by $72-85 \%$ if fully utilised. Profitability is reduced, if automation efforts result in insufficient weed removal compared to manual weeding. Specifically, the benefit gained by robotic weeding was sensitive to the weed intensity and the initial price of the equipment, but a weeding efficiency of under $25 \%$ is required to make it unprofitable.

This approach demonstrates the feasibility of applying and testing operational models in organic farming systems in the continued evaluation and documentation of labour and machinery inputs.

(C) 2005 Silsoe Research Institute. All rights reserved

Published by Elsevier Ltd

\section{Introduction}

In Denmark, the potential for further conversion to organic farming in the next $8-10$ years has been estimated as $15 \%$ of the cultivated area (Christensen \& Frandsen, 2001). Previous projections have estimated a potential of $30 \%$ conversion in 10 years (Action Plan II, 1999). Most recently there has been a decline in the total organically farmed area in Denmark. Such discrepancies indicate that the premises on which these projections are based do not fully capture the factors that determine the rate of conversion. The deliberations of farmers to convert to organic farming range from pure production system considerations to conditions in the market (Christensen \& Frandsen, 2001). By focusing on the production system, there is a need to get a better understanding of the importance of the factors that determine the conversion rate and the economics of organic farming. The required increased knowledge on these factors include type of farm, labour situation and economic constraints.

Organic farming is generally considered more labour intensive than conventional farming, as it is assumed that chemical inputs are substituted by factors, such as increased management knowledge, new practices and techniques, capital and labour (Padel \& Lampkin, 1994). However, the overall effect on labour and machinery usage when carrying out a transition from conventional to organic farming is difficult to predict. Most studies only provide aggregated data, even though labour and 
machinery demand depend, in a complex way, on the type of production and different farm-specific factors such as crop selection, rotation systems, degree of mechanisation and degree of specialisation. The existing literature offers little detailed information about the use of evaluation tools capable of quantifying the labour and machinery demand at various farm levels as a function of internal and external organic farming conditions.

Studies of the labour and machinery usage in the transition from conventional to organic farming have generally assumed a significant increase in the labour demand and capital requirements (MacRae et al., 1990; Dubgaard, 1994; Klemola, 1997; Rapp, 1998). The increase in labour requirement has been assessed as ranging from 15 to $70 \%$ in plant production systems, due to, for example, more rotational crops, increased mechanical weed control and increased crop monitoring (MacRae et al., 1990). Limitations in the availability, quality and affordability of labour forces the organic farmer to discard the use of, for example, sugar beet in the rotation plan (Tersbøl et al., 2001). As a consequence, the farmer tends to adapt to the labour situation in a way that might not fulfil the biological demands of the nutrient cycle on the farm. The introduction of innovative technologies to reduce labour usage is seen as a way of obtaining more biological fulfilling crop rotations in organic farming.

With regard to organic vegetables, Danish growers spend $100-300 \mathrm{~h} \mathrm{ha}^{-1}$ on hand-weeding onions and carrots (Ascard, 1990; Melander \& Rasmussen, 2001) and a time allocation of up to $500 \mathrm{~h} \mathrm{ha}^{-1}$ is necessary under particularly weedy conditions. This commitment is financially demanding for organic growers, not only in terms of direct labour costs, but also in terms of the amount of time consumed for this single task, considering all the other urgent tasks necessary during the growing season. Furthermore, it is difficult to acquire sufficient local labour to carry out the hand weeding.

Saunders et al. (1997) and Dabbert (2001) emphasise that there is a lack of research data on 'real' farm system performance involving an identification and quantification of the technical constraints such as labour and machinery inputs. Also, the professional management principles of conventional farming are increasingly being adopted by organic farmers. This creates a need for a comprehensive knowledge base for the quantification and evaluation of inputs of labour/technology resources in a holistic perspective (Tzilivakis \& Lewis, 2001). The role of technology and knowledge is important, including the evaluation of the context of labour data as related to capital and farm type.

The objective of this study is to design and test farm scenarios representing possible organic farming enter- prises based on milk, pig and plant production. Following the scenario construction, an integrated approach involving the determination of the technical production prerequisites, the establishment of labour budgeting and the derivation of labour profiles is invoked. The currently available knowledge base for operational analyses is supplemented with acquired labour data on managerial tasks and additional labour data on outdoor pig production. Also included is an impact analysis and feasibility study of introducing innovative technologies into the organic production system.

This approach demonstrates the feasibility of bringing operational models and cost estimations to bear on the evaluation and documentation of labour and machinery inputs in organic farm systems. If the image of organic farming is to be promoted to meet consumers' expectations for a good working environment, documentation of the conditions relating to the working environment must be available.

\section{Methodology}

\subsection{Farm scenarios}

A preliminary analysis forms the basis for the design of organic farm scenarios. Scenario planning involves combining factual data and expert evidence to create reasonable and credible scenarios envisioning possible future outcomes (Miller \& Waller, 2003; van der Schilden, 2003). Participants in the scenario construction included research experts and agricultural advisors capable of providing insight and perspective on the possible future of organic farming, while at the same time being aware of the current trends and key elements defining the organic farming environment. Through this interactive process, a technical and biological description of a number of model farms representing different organic production systems (plant, cattle, pigs, mixed vegetables) was elaborated and the technical production characteristics detailed in Nielsen et al. (2003). The description involved organic farm types, which are plausible and internally consistent in terms of logically following what is currently known and expected in the near future (Account Statistics, 2001). Table 1 contains an overview of key production characteristics of the selected farm scenarios: four alternative cropping plans, P0, P1, P2 and P3; three milk production scenarios, M1, M2 and M3; and one pig production system, S1. Also, farm scenario P1 is used as the basis for simulation with band steaming (P1-BS) and robotic weeding (P1-RW). 
Table 1

Farm scenario description (adapted from Nielsen et al., 2003)

\begin{tabular}{|c|c|c|c|c|c|c|c|c|}
\hline & \multicolumn{8}{|c|}{ Farm scenario* $^{*}$} \\
\hline & $P 0$ & $P 1^{\dagger}$ & $P 2$ & $P 3$ & $M 1$ & $M 2$ & M3 & S1 \\
\hline Crops, ha & & & & & & & & 10 \\
\hline Barley/undersown & 10 & 10 & & & 20 & 25 & & 10 \\
\hline Spring barley & & & & & & & & \\
\hline Rye grass & 05 & 05 & & & & & & \\
\hline Grass clover & 05 & 05 & & & 60 & 75 & 60 & \\
\hline Fallow grass clover & & & & & & & & 10 \\
\hline Oats/undersown & 10 & 10 & & 05 & & & & 10 \\
\hline Sugar beet & & 04 & & & & & & \\
\hline Carrots & & 01 & & & & & & \\
\hline Peas & 10 & 10 & & 05 & & & & \\
\hline Triticale/catch crop & 10 & 10 & & & & & & \\
\hline Potatoes & 10 & 05 & & 10 & & & & \\
\hline Lucerne & & & 26 & & & & & \\
\hline Fallow grass & & & 04 & & & & & \\
\hline Winter wheat & & & 15 & & & & & \\
\hline Spring wheat & & & & & & 25 & & \\
\hline Maize for silage & & & & 10 & 20 & & & 10 \\
\hline Barley/peas/whole crop & & & 15 & 10 & 20 & 25 & 30 & \\
\hline Lupin & & & & 10 & & & & 10 \\
\hline Animals, number & & & & & & & & \\
\hline Cows & & & & $10^{*}$ & 75 & 110 & 93 & \\
\hline Sows & & & & & & & & 70 \\
\hline
\end{tabular}

*'P', 'M' and 'S' indicate arable, dairy, and pig producing scenarios, respectively.

${ }^{\dagger}$ Farm scenario P1 is used as the basis for simulation with band-steaming (P1-BS) or robotic weeding (P1-RW).

*Additional, farm scenario P3 include 10 suckler cows and rearing as part of representing an versatile farm.

\subsection{On-farm analyses}

Empirical studies on managerial efficiency are scarce (Trip et al., 2002). In terms of allocating time and labour to the management of the technical and biological processes in agriculture, previous attempts have often included an arbitrary assessment of a particular addition to the manual labour input (Nielsen \& Sørensen, 1993; Achten, 1997; Sørensen et al., 2003). The data collection protocol for the managerial tasks in this study included a farm survey on 18 pre-selected groups of respondents divided evenly between organic crop, dairy and pig production. The surveys included targeted questionnaires administered by an experienced researcher during each interview. The questionnaires included both closed and open-ended questions and followed established guidelines for surveys (Fink \& Kosecoff, 1998). Efforts were made to avoid any bias in the process of interviewing farmers by introducing standardised lists of options to be answered. The results from the surveys allowed for the allocation of the labour requirements for tasks, such as production management in general, professional advancement, monitoring in the animal houses and the fields.
A survey of six organic pig farmers was conducted to determine the daily and periodic labour requirements for outdoor pig production.

The sampling method in both surveys was a combination of methods based on the assessments from agricultural advisers and the advantage of the respondent's ability to identify the population under study. This non-random method is considered feasible in terms of the main objective being a pilot study engaged in an exploratory analysis (Lohr, 1999).

\subsection{Analytical and modelling procedures}

Based on the information in Table 1, the model ØPLAN (Tvedegaard, 2002) was used to quantify a number of prerequisites constituting the basis for the subsequent operational analyses. This dynamic planning model evaluates the economic consequences during conversion to organic farming as a function of the production technical relations and prevailing organic provisions. By using selected parts of the model, many prerequisites including crop plans, fertiliser plans for animal manure, crop yields, feed production and feed 


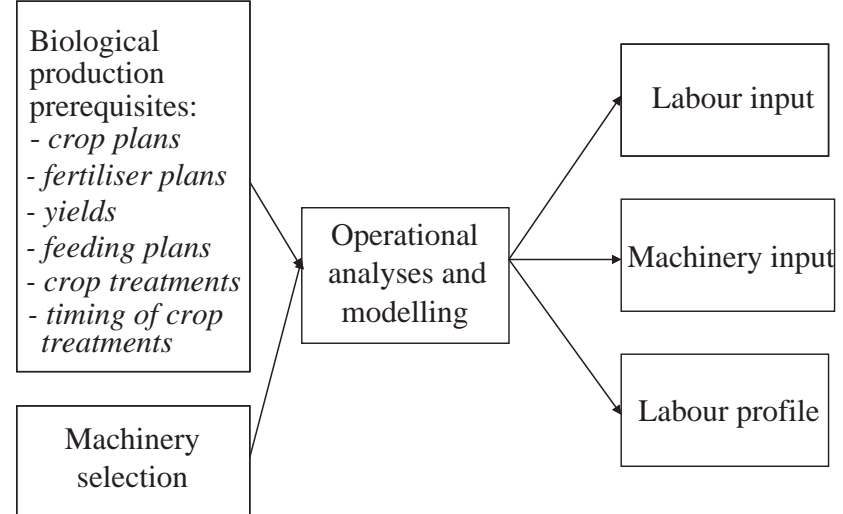

Fig. 1. Procedural outline for analysing and modelling scenario operations

plans, individual crop treatments and execution time for treatments were derived (Fig. 1). In addition, the machinery complement was selected and the capacity of individual machinery items was determined based on a requirement assessment fulfilling average timeliness thresholds as specified by Søgaard and Sørensen (2004).

Upon quantification of all prerequisites, the technical operational analyses of expected labour requirements and machine performance were carried out using the generalised operations model DRIFT (Nielsen \& Sørensen, 1993; Achten, 1997) supplemented with modules for specific operations (Sørensen et al., 2003; Sørensen, 2003). These models enable the evaluation of operational performance to be adjusted to farm-specific conditions such as field size and shape, machinery capacity and transport distance. Specifically, the labour requirement for outdoor pig production was based on generalised data derived from a targeted study of six pilot farms (Nielsen et al., 2003). The model estimates detailed labour and machinery demands and evaluates the scheduling of the operations to be performed. The labour requirement may be estimated for an operation, a specific enterprise, or the whole farm, given technical-biological perquisites such as machinery system, machinery size, field size, crop yield and with the intention of only identifying system-related differences. According to Nielsen and Sørensen (1993), an arbitrary addition covering the management tasks is included in the total labour requirement. This addition amounts to $15.7 \%$ of the direct operational work load (see Section 4.1).

The operational technical evaluation of the model farms includes both traditional working methods and innovative technologies such as band steaming and robotic weeding. The labour input, performance data and relevant economic parameters for these technologies are based on preliminary test data and expert assess- ments. These data form the basis for analysing the costs and benefits. The economic consequences of implementing innovative technologies have been calculated using conventional methods for estimating depreciation, interest and maintenance of machinery (Madsen, 2003). The costs were distributed over a 10-year-lifetime as well as over the number of hectares being treated by the machinery. A supplemental notion in terms of the maximum acquisition value (MAV) is also used to assign profitability, i.e. the capital amount that may be invested in the new technology to achieve the same net result as with the traditional technology.

\section{Introduction of innovative technologies}

The continued development of organic farming requires that innovative technologies are introduced in order to fulfil the perceived need for increased professionalism, specialisation and use of rational production methods (Christensen \& Frandsen, 2001). The technologies for the organic sector need to be integrated and must conform to a number of sustainability factors instead of simply being redesigned conventional machinery (Hagras et al., 2002). Reluctance to adopt novel technologies in organic farming requires special consideration (Bond \& Grundy, 2001). Assuming full technology acceptance, two examples of technology adoption are envisaged, focusing on labour-intensive areas of organic production such as the substitution of manual weeding with mechanical weeding.

\subsection{Band steaming for intra-row weed control}

A new prototype of an integrated machinery system for weeding, which involves band steaming for intra-row weed control, has been developed (Melander et al., 2004). The soil is thermally treated in a narrow bandwidth of $8 \mathrm{~cm}$ around the crop rows at a depth of $5 \mathrm{~cm}$ prior to crop establishment in order to reduce weed seedling emergence. The subsequent sowing is carried out automatically following a track pre-set by the bandsteamer. The control of inter-row weeds is carried out by means of traditional hoeing. The system is intended to increase the yield of organically grown row crops such as outdoor vegetables, maize and sugar/ fodder beet. Table 2 outlines the operational parameters for the system divided into two machinery sizes.

\subsection{Robotic weeding}

The ultimate objective of robotic weeding is to reduce the manual labour requirement for organic vegetables 
Table 2

Operational parameters and the price of a band steamer (adapted from Dyring, 2002)

\begin{tabular}{lcc}
\hline & \multicolumn{2}{c}{ Generator $_{\text {power }}^{*}$} \\
\cline { 2 - 3 } & $726 \mathrm{~kW}$ & $1493 \mathrm{~kW}$ \\
\hline Capacity, ha h $^{-1}$ & $0 \cdot 2$ & $0 \cdot 4$ \\
Bandwidth, cm & 8 & 8 \\
Velocity, $\mathrm{km} \mathrm{h}^{-1}$ & $1 \cdot 1$ & $2 \cdot 2$ \\
Turning time, service time, etc., \% & 10 & 10 \\
Investment, $\mathrm{\epsilon}^{\dagger}$ & 40323 & 56152 \\
\hline
\end{tabular}

*The generator power is the rated output from the commercial available steam generators.

${ }^{\dagger}$ Currency conversion: $100 €=744$ DKK.

Table 3

Expected performance data and price for a weeding robot

\begin{tabular}{|c|c|c|}
\hline Performance & Sugar beet & Maize \\
\hline Velocity, $\mathrm{m} \mathrm{s}^{-1}$ & $0 \cdot 50$ & 1.00 \\
\hline Field efficiency $*, \%$ & 80 & 80 \\
\hline Working width, cm (2 rows) & 100 & 150 \\
\hline Area capacity ${ }^{\dagger}$, ha $^{-1}$ & $0.18($ net 0.23$)$ & $0.54($ net 0.68$)$ \\
\hline Service time $* \%$ & 15 & 15 \\
\hline Investment $^{\S}, €$ & \multicolumn{2}{|c|}{26882} \\
\hline
\end{tabular}

\footnotetext{
${ }^{*}, \dagger$ Field efficiency and area capacity are estimated by simulating the driving pattern on a 2 ha field $(100$ by $200 \mathrm{~m})$ using a generalised operation model (Nielsen \& Sørensen, 1993)

${ }^{*}$ The service time includes labour allocated to maintain the robot operational analogous to traditional field operation (Nielsen \& Sørensen, 1993).

${ }^{\S}$ The expected initial price of the weeding robot is assessed by combining the concepts of automated guided vehicles (AGVs) with the need for additional subsystems and sensors to achieve the functionality of the perceived weeding robot (Garcia-Alegre et al., 2001; Blackmore et al., 2002).
}

and sugar beet by $50-100 \%$ (Griepentrog \& Søgaard, 2003). Current prototype technologies are based on a small autonomous vehicle, equipped with vision systems for precision guidance and for plant recognition, as well as active tools for weed removal (Åstrand \& Baerveldt, 2002). In some cases, the technology requires that the positions of the individual seeds are logged prior to the weeding during sowing, as opposed to pure sensing of the target crop and weeds (Blasco et al., 2002). This approach enables the weeding robot to broadly recover the plant positions, while the precise position is retrieved by using computer vision, enabling weed removal close to the crop plant. Weeding between the rows is done using traditional hoeing, with or without automatic guidance (Tillett et al., 2002).
The operational capability of the weeding robot is based on experiences from the development of an autonomous platform (Bak \& Jacobsen, 2004; Sørensen et al., 2002) for monitoring in-field weeds as the basis for weed mapping, displaying the intensity and types of weeds distributed throughout the field. Based on an expected lower velocity of the weeding robot than when running in monitoring mode and experiences from the development of a weeding machine for maize (Griepentrog \& Søgaard, 2003), the operational performance data shown in Table 3 were derived.

Recent research (Terawaki et al., 2003) indicates that the prerequisites with respect to velocity, and thereby area capacity, might be lower than the data presented in Table 3. The economic consequences of such a deviation in capacity are discussed in Section 4.3.

\section{Results and discussion}

\subsection{Labour and machinery input}

The labour demand was estimated for each of the farm scenarios (Table 4). The labour requirement is relatively high for the scenario $\mathrm{P} 0$. The considerable input of labour is caused by the growing of potatoes on $17 \%$ of the total adjoining area. In the case of farm scenario P1, potatoes, sugar beet, and carrots are grown on $8.3 \%, 6.7 \%$ and $1.7 \%$ of the area, respectively. The introduction of sugar beet and carrots to P1 increases the labour demand by $53 \%$ compared with $\mathrm{P} 0$ due to the manual weeding and the cleaning and sorting of the carrots. Maintaining the altered crop plan and introducing robotic weeding and band steaming for weed management in sugar beet reduces the labour demand by $85 \%$ and $83 \%$, respectively. The reduction in labour demand for carrots equals $60 \%$ for both technologies, because much manual labour must still be devoted to the cleaning and sorting of the carrots.

As observed, the amount of labour input differs considerably between the different production configurations within the plant production system, and the allocation of the labour input during the year is also affected. Figure 2 shows the labour profiles for the four farm scenarios (P0, P1, P1-RW and P1-BS). The scenario P1 demonstrates a high labour demand for manual weeding from week 22 to week 27 in contrast to the labour demand for P1-RW and P1-BS. In general, the farm scenarios $\mathrm{P} 0, \mathrm{P} 1-\mathrm{RW}$ and $\mathrm{P} 1-\mathrm{BS}$ reflect the seasonal pattern of work throughout the spring and autumn.

In the case of farm scenario $\mathrm{P} 2$, the labour requirement is relatively low, caused by the fact that $50 \%$ of the area is cropped with lucerne and the rest is cropped with 
Table 4

Farm size, number of animal units (LU), labour demand and annual work input (Nielsen et al., 2003)

\begin{tabular}{|c|c|c|c|c|c|}
\hline \multirow[t]{2}{*}{ Farm scenario* } & \multirow{2}{*}{$\begin{array}{c}\text { Area, } \\
\text { ha }\end{array}$} & \multirow{2}{*}{$\begin{array}{c}\text { Number, } \\
L U^{\dagger}\end{array}$} & \multicolumn{2}{|c|}{ Labour demand } & \multirow{2}{*}{$\begin{array}{c}\text { Annual work input } \\
\text { factor }^{\ddagger}\end{array}$} \\
\hline & & & $h h a^{-1}$ & $h L U^{-1}$ & \\
\hline $\mathrm{P} 0$ & 60 & & $16 \cdot 6$ & & $0 \cdot 6$ \\
\hline $\mathrm{P} 1$ & 60 & & $25 \cdot 3$ & & 0.9 \\
\hline P1-RW & 60 & & $15 \cdot 1$ & & 0.5 \\
\hline P1-BS & 60 & & $15 \cdot 2$ & & $0 \cdot 5$ \\
\hline $\mathrm{P} 2$ & 60 & & $6 \cdot 5$ & & $0 \cdot 2$ \\
\hline P3 & 50 & 15 & $10 \cdot 9$ & $37 \cdot 1$ & 0.7 \\
\hline M1 & 120 & 112 & $6 \cdot 4$ & $23 \cdot 9$ & $2 \cdot 1$ \\
\hline M2 & 150 & 168 & $6 \cdot 7$ & 19.4 & $2 \cdot 6$ \\
\hline M3 & 90 & 139 & $6 \cdot 1$ & $21 \cdot 2$ & $2 \cdot 1$ \\
\hline $\mathrm{S} 1$ & 60 & 73 & 7.9 & $39 \cdot 6$ & $2 \cdot 0$ \\
\hline
\end{tabular}

*'P', 'M' and 'S' indicate arable, dairy, and pig producing scenarios, respectively.

${ }^{\dagger} \mathrm{LU}$, livestock unit.

${ }^{\ddagger}$ The standard work input contains $1665 \mathrm{~h}$ of work per year.

cereals and fallow land. Since silo maize is included for scenario P3, supplemental labour input for weeding is required, causing a relatively high input of labour despite cropping mainly with cereals.

The yearly labour input for the arable farm scenarios ranges between 0.2 and 0.9 of the annual one-person work of $1665 \mathrm{~h}$. The 60 ha arable farm scenarios are only capable of supplying part-time employment. In order to sustain a full-time employment more labour-intensive, and probably more profitable, crops are required.

The labour demand in the field is relatively low for the milk production scenarios, mainly because of the relatively large areas of grassland used for grazing and silage. No labour-intensive crops such as fodder beet are grown. The labour demand is fractionally higher at the pig farm, caused by the growing of silo maize and lupines and additional catch crops. The labour demand per livestock units (LU) in the livestock production systems ranges from 19.4 to 39.6 man hours, which provides the possibility of employing outside help and thereby makes it easier to achieve harmony in the overall workload.

The operations performed by a contractor in the various scenarios range from 7 to $65 \%$ of the overall field work (Table 5). The use of a contractor is more widely adopted in the milk production scenarios, where specialised machinery often is needed for manure handling, silage making, combine harvesting and other tasks with only seasonal utilisation. The high-cost operations allocated to contractors is evident from a comparison of the share of field work performed by contractors and total cost, since the share of total cost exceeds the share of field work.

\subsection{Targeted model validation}

The results of the empirical studies on the managerial efficiency for different organic production types indicated that the average management efforts ranged from 13.7 to $19.0 \%$ of the total labour input (Fig. 3) with a gross average of $15.7 \%$. Statistical testing of the hypothesis that the management efforts for the different production systems are equal cannot be rejected $(P>0.05)$. Based on these findings, the gross average value of $15.7 \%$ is used in the labour input estimations.

\subsection{Band steaming for intra-row weed control}

The considerable reduction in labour demand contributes to a significant improvement of the economic outcome. If the system is assumed to be a part of the machinery complement for farm scenario P1-BS, a decrease in gross margin by $270 € \mathrm{ha}^{-1}$ is expected, while an increase of $986 € \mathrm{ha}^{-1}$ can be obtained if a contractor carries out the operation (Table 6). In the case of a contractor performing the operation the annual operating hours are $135 \mathrm{~h}$, while the actual utilisation for the farm scenario $\mathrm{P} 1-\mathrm{BS}$ only amounts to $12.5 \mathrm{~h} \mathrm{yr}^{-1}$. The potential operating hours of $135 \mathrm{~h} \mathrm{yr}^{-1}$ are based on Danish weather conditions, where during the seeding season an operational window of 15 days of 12 each and a workability of $75 \%$ is expected in a normal year (Madsen, 2003).

A critical prerequisite with respect to the improved profitability is the efficiency with which the band steaming is able to replace manual weeding. If a weeding 

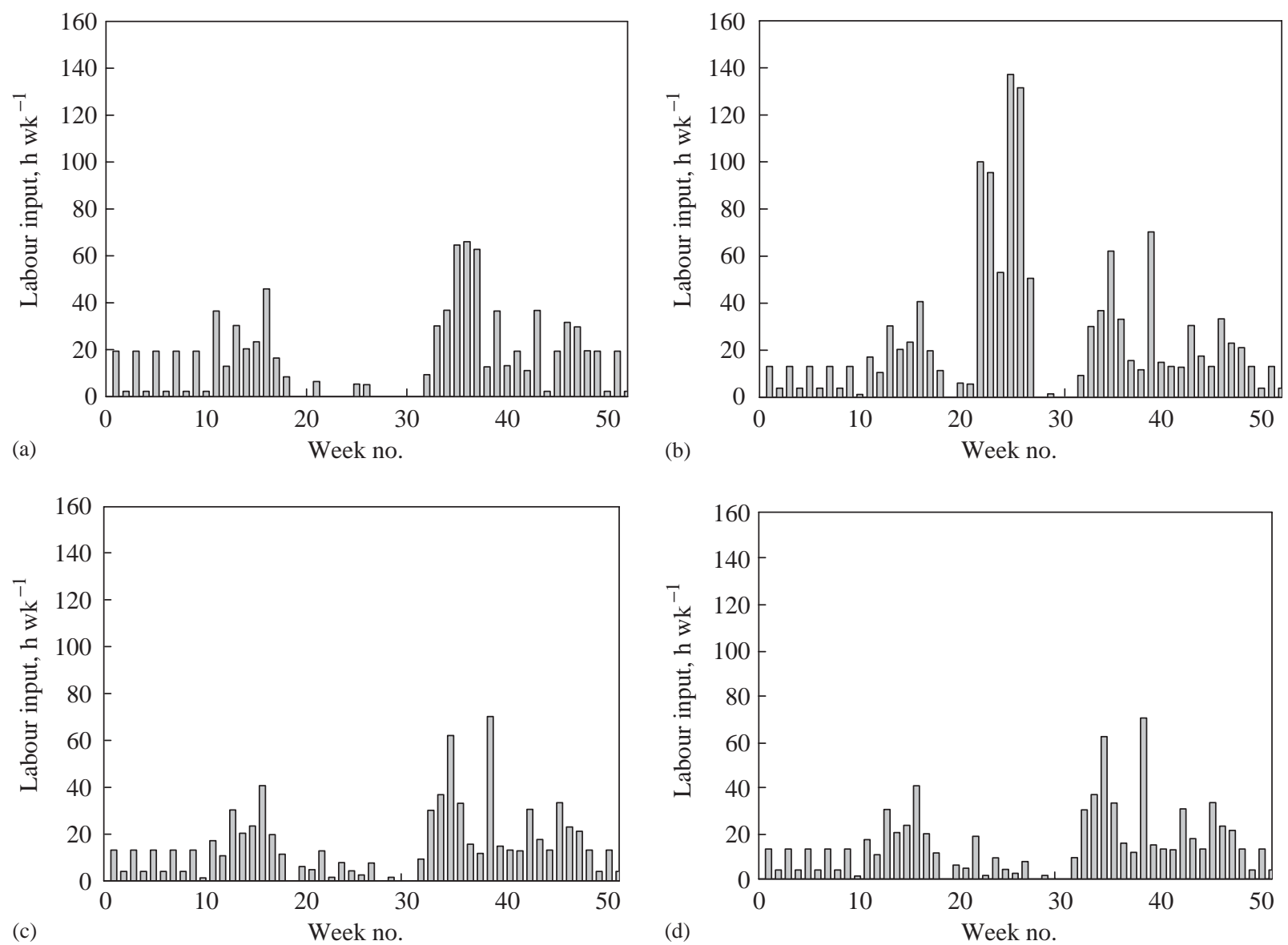

Fig. 2. Labour profiles for the different scenarios for arable production: (a) basic arable (P0); (b) alternative arable precision sown crops (P1); (c) alternative arable with robotic weeding ( $P 1-R W)$; and (d) alternative arable with band steaming (P1-BS)

Table 5

Contractor share of field work and the total cost in the crop production system

\begin{tabular}{|c|c|c|c|}
\hline \multirow[t]{2}{*}{ Farm scenario* } & \multirow{2}{*}{$\begin{array}{c}\text { Area, } \\
\qquad h a\end{array}$} & \multicolumn{2}{|c|}{ Contractor } \\
\hline & & $\%$ of field work & $\%$ of total cost $t^{\dagger}$ \\
\hline $\mathrm{P} 0$ & 60 & $6 \cdot 9$ & 14.4 \\
\hline $\mathrm{P} 1$ & 60 & $8 \cdot 4$ & $11 \cdot 3$ \\
\hline P1-RW & 60 & $14 \cdot 0$ & $14 \cdot 6$ \\
\hline P1-BS & 60 & $15 \cdot 9$ & $12 \cdot 4$ \\
\hline $\mathrm{P} 2$ & 60 & $28 \cdot 1$ & 4.9 \\
\hline P3 & 50 & $21 \cdot 9$ & 24.5 \\
\hline M1 & 120 & $32 \cdot 7$ & $23 \cdot 9$ \\
\hline M2 & 150 & $29 \cdot 0$ & $20 \cdot 5$ \\
\hline M3 & 90 & $65 \cdot 3$ & $40 \cdot 3$ \\
\hline S1 & 60 & 19.4 & $22 \cdot 3$ \\
\hline
\end{tabular}

*' $\mathrm{P}$ ', ' $\mathrm{M}$ ' and 'S' indicate arable, dairy, and pig producing scenarios, respectively.

${ }^{\dagger}$ Cost of contractors is based on current tariffs per treated hectare or per hour. The total costs include all machinery costs and other input costs allotted to the plant production (Madsen, 2003). efficiency of $75 \%$ is anticipated instead of $100 \%$, which might be the case in specific practical implementations (Hansson \& Svensson, 2004), the profitability is only increased by $642 € \mathrm{ha}^{-1}$ if the operation is carried out by a contractor (or $204 € \mathrm{ha}^{-1}$ using farm-owned machinery). A variation of $\pm 10 \%$ in capacity and price only affects the profitability by approximately $26 € \mathrm{ha}^{-1}$ and $13 € \mathrm{ha}^{-1}$, respectively. Despite the uncertainty, band steaming for intra-row weed control seems promising from an economic point of view if a high degree of utilisation is achieved. Even with a $6 \mathrm{yr}$ lifetime on machinery, the band steaming is profitable for a contractor with 54 ha.

\subsection{Robotic weeding}

From Table 7 it appears that the weeding robot is less expensive to operate than the band-steaming system. Based on an expected price of $€ 26882$, a total cost of 


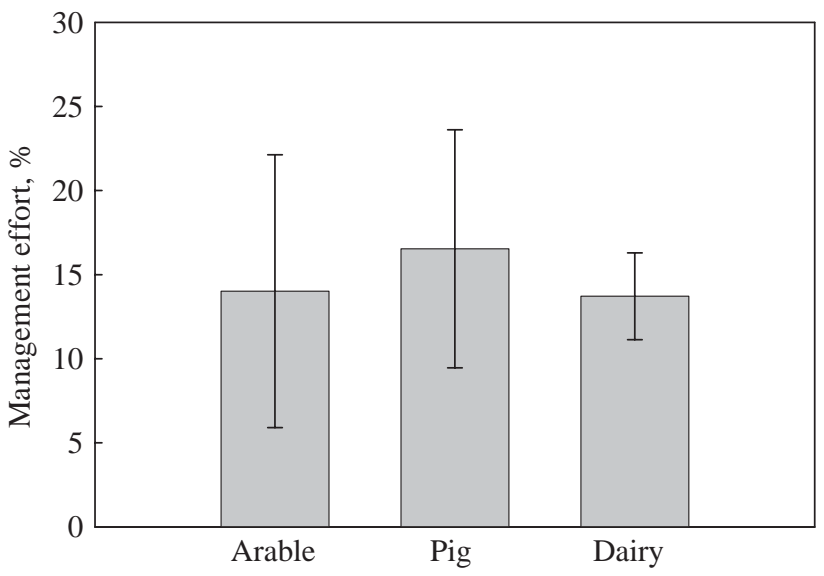

Fig. 3. Management effort measured as a fractional amount of labour to the total farm labour input for three different types of production; the error bars indicate $95 \%$ confidence intervals

Table 6

Cost of implementing band steaming for arable farm scenarios

\begin{tabular}{|c|c|c|}
\hline & \multicolumn{2}{|c|}{ 4-row system $/ 1493 \mathrm{~kW}$} \\
\hline & Owner & Contractor \\
\hline \multicolumn{3}{|l|}{ Utilisation } \\
\hline Annual operating hours, $\mathrm{h} \mathrm{yr}^{-1}$ & $12 \cdot 5$ & 135 \\
\hline Area, ha yr ${ }^{-1}$ & $5 \cdot 0$ & $54 \cdot 0$ \\
\hline \multicolumn{3}{|l|}{ Benefit (manual weeding) } \\
\hline Workload, $\mathrm{h} \mathrm{ha}^{-1}$ & \\
\hline Wage, $€ \mathrm{~h}^{-1}$ & \multicolumn{2}{|c|}{$15 \cdot 3^{*}$} \\
\hline Total benefit, $€$ ha $^{-1}$ & \multicolumn{2}{|c|}{1377} \\
\hline \multicolumn{3}{|l|}{ Variable cost } \\
\hline Oil, $€ \mathrm{ha}^{-1}$ & \multicolumn{2}{|c|}{$117^{*}$} \\
\hline \multicolumn{3}{|l|}{ Fixed cost } \\
\hline Tractor including driver, $€ \mathrm{ha}^{-1}$ & \multicolumn{2}{|c|}{$132^{*}$} \\
\hline Maintenance, $€ \mathrm{ha}^{-1}$ & \multicolumn{2}{|c|}{$13 \cdot 4^{*}$} \\
\hline Depreciation and interest ${ }^{\dagger}, € \mathrm{ha}^{-}$ & ${ }^{1} 1385$ & 128 \\
\hline Total cost, $€ \mathrm{ha}^{-1}$ & 1647 & 390 \\
\hline Reduced costs, $\%$ & -20 & 72 \\
\hline
\end{tabular}

* Cost estimations according to Dyring (2002).

${ }^{\dagger}$ The lifetime is set at $10 \mathrm{yr}$ and the interest is set at $4 \%$.

$744 € \mathrm{ha}^{-1}$ could be expected for an organic farm scenario like P1-RW. A better utilisation of the capacity can be obtained if a contractor or a cooperative of organic farmers carries out the operation as more potential operating hours are utilised. In an average year, 20 days of acceptable weather conditions (of which $75 \%$ are workable) are expected, and if the weeding robot is able to operate for $12-20 \mathrm{hday}^{-1}$, respectively, depending on the need for daylight, $180-300 \mathrm{~h} \mathrm{yr}^{-1}$ are available. The costs are reduced by 79 and $85 \%$ compared with manual weeding.
Table 7

Cost of implementing robotic weeding for arable farm scenario

\begin{tabular}{|c|c|c|c|}
\hline \multirow[b]{2}{*}{ Utilisation } & \multirow[t]{2}{*}{ Own } & \multicolumn{2}{|c|}{ Contractor } \\
\hline & & & \\
\hline Annual operating hours, $\mathrm{h} \mathrm{yr}^{-1}$ & 28 & 180 & 300 \\
\hline Area*, ha yr ${ }^{-1}$ & $5 \cdot 0$ & $16 \cdot 2$ & $27 \cdot 0$ \\
\hline \multicolumn{4}{|l|}{ Benefit (manual weeding) } \\
\hline Workload, $\mathrm{h} \mathrm{ha}^{-1}$ & & 90 & \\
\hline Wage, $€ \mathrm{~h}^{-1}$ & & $15 \cdot 3$ & \\
\hline Total benefit, $€ \mathrm{ha}^{-1}$ & & 1377 & \\
\hline \multicolumn{4}{|l|}{ Variable cost } \\
\hline Electricity $^{\dagger}, € \mathrm{ha}^{-1}$ & & $7 \cdot 5$ & \\
\hline Wages, $€ \mathrm{ha}^{-1}$ & & 12.9 & \\
\hline \multicolumn{4}{|l|}{ Fixed cost } \\
\hline Maintenance ${ }^{\star}, € \mathrm{ha}^{-1}$ & & $60 \cdot 3$ & \\
\hline Depreciation and interest $^{\S}, € \mathrm{ha}^{-1}$ & 663 & 204 & 122 \\
\hline Total cost, $€$ ha- 1 & 744 & 285 & 203 \\
\hline Reduced costs, & 46 & 79 & 85 \\
\hline
\end{tabular}

*The denoted area is the area treated twice yearly by the current technology.

${ }^{\dagger}$ The power cost is set to $1.3 € \mathrm{~h}^{-1}$ by analogy to the concept of a Christmas tree weeder (Blackmore et al., 2002).

${ }^{\ddagger}$ Maintenance cost is estimated as 0.4 per thousand of the initial price per operating hour as compared with a modern combine harvester (Laursen, 1993).

${ }^{\S}$ The lifetime is set at 10 years and the interest is set at $4 \%$.

The profitability improvements shown in Table 7 are based on a reduction of manual weeding by $100 \%$. However, Nørremark and Griepentrog (2004) and Lamm et al. (2002) indicate that the weeding efficiency would presumably be lower and could easily be reduced by $20-25 \%$. If an efficiency of $75 \%$ is assumed, the cost reduction is no longer around $80 \%$ but is reduced to $47-56 \%$ dependent on the degree of utilisation. Despite this reduction, the technology is still profitable to implement regardless of ownership. In an economic setting, the uncertainty of the purchase price is expected to significantly influence the profitability. Focusing on the uncertainty of costs and benefits by implementing robotic weeding, the weeding efficiency, weed intensity, purchase price of the machinery, utilisation and area capacity are key parameters. A reduction in the lifetime from 10 to $6 \mathrm{yr}$ would change the total cost reduction from around 80 to $67 \%$. In Fig. 4, the relationship between weeding efficiency and maximum acquisition value of the technology is illustrated at different levels of weed intensity and utilisation. The maintenance cost per hour is calculated as 0.04 pct of the acquisition value.

From Fig. 4 it can be seen that, even at a low level of weed intensity and utilisation, the maximum acquisition value for a rational organic farmer would be just under $€ 40000$. However, in the case of high utilisation $(300 \mathrm{~h})$ 


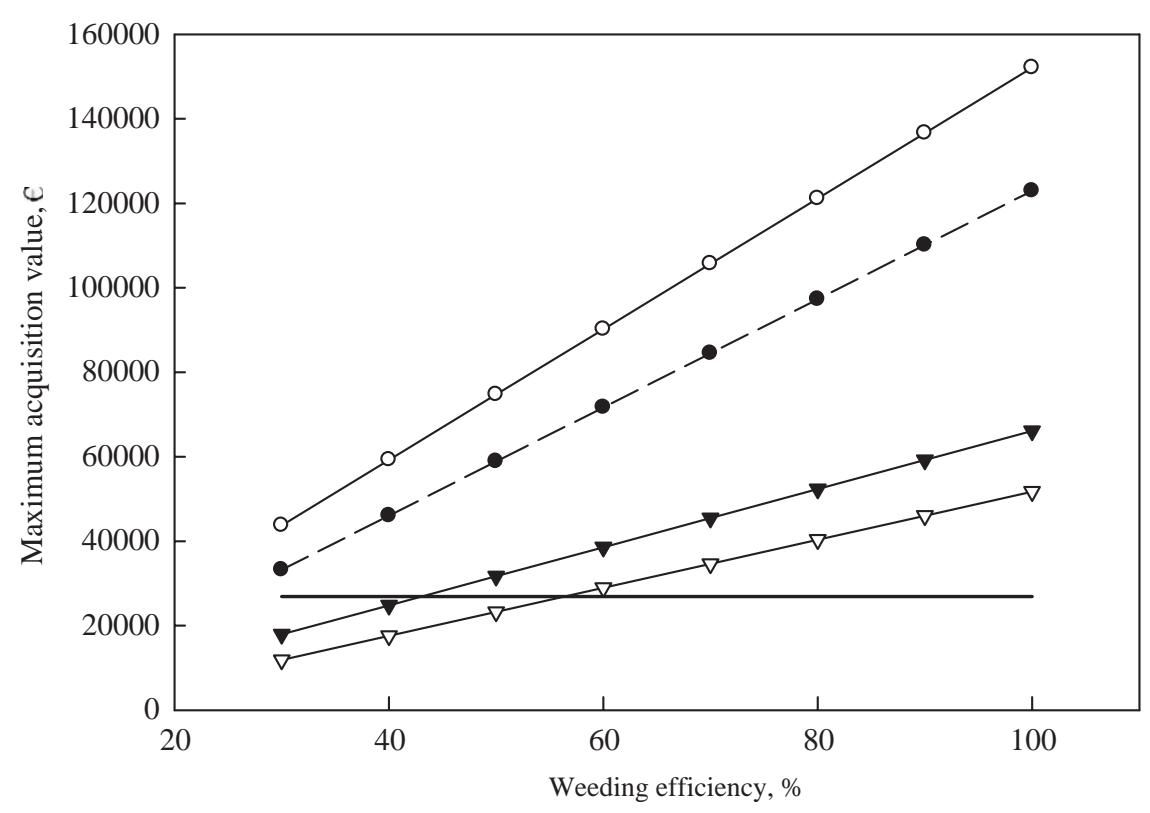

Fig. 4. The relationship between weeding efficiency and maximum acquisition value at different levels of weed intensity and utilisation. The horizontal black line indicates the expected capital requirements for a robotic weeder; the first number in the legend indicates whether the weed intensity is high (90) or low (40) measured by the number of hours that manual weeding would require, and the utilisation is specified by the last number as either 180 or $300 \mathrm{hyr}^{-1}: \circ, 90-300 ; \bullet, 90-180 ; \nabla, 40-300 ; \nabla, 40-180$

and high weed intensity, a maximum acquisition value of around $€ 110000$ is estimated. If, on the other hand, the actually obtained working velocity is lower than expected, which might be the case under certain circumstances as indicated by Terawaki et al. (2003), a higher utilisation and weeding efficiency is required to pay off the expected investment cost.

\section{Conclusion}

Detailed operational analyses of organic farm scenarios formed the basis for predicting the labour and machinery input for all work operations in the field and the animal houses, selection of machinery types and the estimation of machinery sizes. The results show that the labour demand ranges from 6.1 to $25.3 \mathrm{~h} \mathrm{ha}^{-1}$ for fieldwork and from 19.4 to $39.6 \mathrm{~h}$ per livestock unit for work in the animal houses.

The introduction of sugar beet and carrots into a specific crop plan increases the labour demand by $53 \%$, because of the manual weeding and the cleaning and sorting of the carrots. By maintaining an altered crop plan and introducing the new technologies such as robotic weeding and band steaming for weed management, the labour demand is reduced by 85 and $83 \%$, respectively, for sugar beet production, and $60 \%$ when growing carrots.
The significant reduction in labour demand reduces the cost of growing carrots and sugar beet considerably. Assuming that the technologies are highly utilised, a gain in profitability of about $72-85 \%$ can be obtained. If the machinery utilisation is low (5ha), the cost is reduced by $46 \%$ and increased by $20 \%$ in the case of robotic weeding and band steaming, respectively.

The cost reduction is $47-56 \%$ for both technologies if a weeding efficiency of only $75 \%$ is achieved instead of $100 \%$, assuming high utilisation. Apart from the weeding efficiency and the level of utilisation, the profitability of both technologies is sensitive to weed intensity and the initial price in the case of robotic weeding. Assuming a weeding efficiency of $75 \%$, yearly use of $180 \mathrm{~h}$ and low weed intensity, a maximum acquisition value of under $€ 40000$ is estimated for the robotic weeding technology. In general, the analysis of the economic consequences of implementing the new technologies indicates that robotic weeding is preferable to the band steamer if uncertainty is neglected. There is more uncertainty related to robotic weeding, but even in the worst case the technology is still profitable.

Since the selected new technologies only reduce the inputs of labour and cost when growing beet and vegetables, a limited part of the organic sector is affected. As a consequence, the devised limited application of innovative technologies is not likely to cause a breakthrough in lowering of the production costs in the 
organic sector as a whole. However, the perspective is that other types of operations will be automated in a continued effort of having multiple operations giving the same promising results as obtained in this study. Also, automation presents itself as the only solution for farmers faced with labour unavailability for weeding special crops.

\section{References}

Account Statistics (2001). Account Statistics for Organic Farming. Series G, No. 6, Danish Institute of Agricultural and Fisheries Economics, Copenhagen, Denmark

Achten J (1997). Models, Methods and Database for Labour and Machinery in Agriculture. CIGR Working Group 17, Wageningen, The Netherlands

Action Plan II (1999). Developments in Organic Farming: English Summary. Ministry of Food, Agriculture and Fisheries, Danish Directorate for Development, Copenhagen, Denmark

Ascard J (1990). Weed control in ecological vegetable farming. In: Proceedings of the Ecological Agriculture NJF Seminar 166 (Granstedt A, ed), pp 178-184. Scandinavian Association of Agricultural Scientists, Swedish University of Agricultural Sciences, Alnarp, Sweden

Åstrand B; Baerveldt A-J (2002). An agricultural mobile robot with video-based perception for mechanical weed control. Autonomous Robots, 13, 21-35

Bak T; Jakobsen H (2004). Agricultural robotic platform with four wheel steering for weed detection. Biosystems Engineering, 87(2), 125-136

Blackmore S; Have H; Keller B; Fountas S; Nielsen H; Theilby F (2002). Autonomous weeders for Christmas tree plantations - a feasibility study. (Have H, eds.). Pesticide Research No. 59, 2002, Danish Environmental Protection Agency

Blasco J; Aleixos N; Roger J M; Rabatel G; Molto E (2002). Robotic weed control using machine vision. Biosystems Engineering, 83, 149-157

Bond W; Grundy A C (2001). Non-chemical weed management in organic farming systems. Weed Research, 41, 383-405

Christensen J; Frandsen S E (2001). Økonomiske perspektiver for økologisk jordbrug. [Economic perspectives for the development of organic farming.] Report No. 124, Danish Institute of Agricultural and Fisheries Economics, Copenhagen, Denmark

Dabbert S (2001). Elements of a European action plan for organic farming. In: Proceedings of the European Conference: Organic Food and Farming, 10-11 May, Copenhagen, Denmark

Dubgaard A (1994). Economics of organic farming in Denmark. In: The Economics of Organic Farming: An International Perspective (Lampking $\mathrm{N} \mathrm{H}$; Padel S, eds), pp 119-129. CAB International, Wallingford, Oxon, UK

Dyring (2002). En foreløbig evaluering af de markedsorienterede perspektiver for et integreret maskinsystem for termisk båndbehandling. [A preliminary evaluation of the market oriented perspectives for an integrated machinery system for thermal band-heating.] Danish Institute of Agricultural Sciences and J. Drying International ApS

Fink A; Kosecoff J (1998). How to Conduct Surveys: A Stepby-Step Guide. Sage Publications, Thousand Oaks, USA
Garcia-Alegre M C; Ribeiro A; Garcia-Perez L; Martinez R; and Guinea D (2001). Autonomous Robot in Agriculture Tasks. In: 3rd European Conference on Precision Agriculture, June 2001, Montpellier, pp 25-30

Griepentrog H W; Søgaard H (2003). Robotic weeding in sugar beet. In: Proceedings of the NJF 22nd Congress, Nordic Agriculture in Global Perspective, 1-4 July, Turku, Finland

Hagras H; Colley M; Callaghan V; Carr-West M (2002). Online learning and adaptation of autonomous mobile robots for sustainable agriculture. Autonomous Robots, 13, $35-37$

Hansson D; Svensson S E (2004). Steaming soil in narrow strips for intra-row weed control in sugar beet. In: Proceedings of the 6th EWRS (European Weed Research Society) Workshop on Physical and Cultural Weed Control, Lillehammer, Norway, 8-10 March 2004, p 125

Klemola E (1997). Factors influencing labour usage in ecological farming. In: Proceedings of the XXVII CIOSTA-CIGR Congress, Hungary, pp 185-190

Lamm R D; Slaughter D C; Giles D K (2002). Precision weed control system for cotton. Transactions of the ASAE, 45(1), 231-238

Laursen B (1993). Omkostninger for landbrugsmaskiner i relation til maskinernes alder og årlige anvendelse. [Machinery costs as a function of machine age and yearly utilization.] Departmental Report. Danish Institute of Agricultural and Fisheries Economics, Copenhagen, Denmark

Lohr S (1999). Sampling: Design and Analysis. Duxbury Press, USA

MacRae R J; Hill S B; Mehuys G R; Henning J (1990). Farmscale Agronomic and Economic Conversion from Conventional to Sustainable Agriculture. EAP Publication 108, McGill University, Canada

Madsen N A (2003). En driftsøkonomisk analyse af økologisk jordbrug — med focus påny teknologi og regelændringer. [A production economic analysis of organic farming - focusing on new technologies and legislative restrictions.] MSc Thesis, Agricultural Economics, Department of Economics and Natural Resources, The Royal Veterinary and Agricultural University, Copenhagen

Melander B; Jørgensen MH; Elsgaard L (2004). Recent results in the development of band steaming for intra-row weed control. In: Proceedings of the 6th EWRS (European Weed Research Society) Workshop on Physical and Cultural Weed Control, Lillehammer, Norway, 8-10 March 2004

Melander B; Rasmussen G (2001). Effects of cultural methods and physical weed control on intrarow weed numbers, manual weeding and marketable yield in direct-sown leek and bulb onion. Weed Research, 41, 491-508

Miller K; Waller H G (2003). Scenarios, real options and integrated risk management. Long Range Planning, 36, 93-107

Nielsen V; Sørensen C G (1993). DRIFT: A Program for Calculation of Work Requirement, Work Capacity, Work Budget, Work Profile. Bulletin No. 53, National Institute of Agricultural Engineering, Horsens, Denmark

Nielsen V; Sørensen C G; Mortensen H S (2003). Scearieanalyser vedr. driftsteknisk indsats $\mathrm{i}$ økologisk jordbrug. [Scenario analysis concerning labour and machinery input in organic farming.] Internal Report No. 188, Danish Institute of Agricultural Science, Horsens, Denmark

Nørremark M; Griepentrog H W (2004). Analysis and definition of the close-to-crop area in relation to robotic 
weeding. In: Proceedings of the 6th EWRS (European Weed Research Society). Workshop on Physical and Cultural Weed Control, Lillehammer, Norway, 8-10 March 2004

Padel S; Lampkin N (1994). Conversion to organic farming: an overview. In: The Economics of Organic Farming: An International Perspective (Lampkin N H; Padel S, eds), pp 295-313. CAB International, Wallingford, Oxon, UK

Rapp S (1998). Oko-Landbau schafft Arbeitsplatze! [Organic farming provides employment.]. Bio-Land, 2, 34-35

Saunders C; Manhire J; Campbell H; Fairweather J (1997). Organic farming in New Zealand: an evaluation of the current and future prospects including an assessment of the research needs. MAF Policy Technical Paper No. 97/13, MAF Wellington, New Zealand

Søgaard H; Sørensen C G (2004). A model for optimal selection of machinery sizes within the farm machinery system. Biosystems Engineering, 89(1), 13-28

Sørensen C G (2003). A model of field machinery capability and logistics: the case of manure application. Agricultural Engineering International: CIGR Journal of Scientific Research and Development (Manuscript PM 03 004), V

Sørensen C G; Jacobsen B H; Sommer S G (2003). An assessment tool applied to manure management systems using innovative technologies. Biosystems Engineering, 86, $315-325$

Sørensen C G; Olsen H J; Ravn A P; Makowski P (2002). Planning and operation of an autonomous vehicle for weed inspection. In: ASAE Annual International Meeting/CIGR XVth World Congress, Chicago. Paper 02 1177. ASAE, St Joseph, Michigan, USA
Terawaki M; Kataoka T; Okamoto H; Hata S (2003). Development af automatic weeding thinner for sugar beet. 2003 ASAE Annual International Meeting, Las Vegas, USA, Paper number 033076

Tersbøl M; Mikkelsen G; Rasmussen I; Christensen S (2001). Preventive Measures Directed at Weeding Problems, Mechanical Weed Removal and Effects on the Seed Pool. Danish Agricultural Advisory Centre, Danish Institute of Agricultural Sciences, Aarhus, Denmark

Tillett N D; Hague T; Miles S J (2002). Inter-row vision guidance for mechanical weed control in sugar beet. Computers and Electronics in Agriculture, 33, 163-177

Trip G; Thijssen G J; Renkema J A; Huirne R B M (2002). Measuring managerial efficiency: the case of commercial greenhouse growers. Agricultural Economics, 27, 175-181

Tvedegaard N (2002). Organic Milk Production: Economic Analyses. Report No. 137, Danish Research Institute of Food Economics, Copenhagen, Denmark, [in Danish]

Tzilivakis J; Lewis K A (2001). The development of software to support planning conversion to organic agriculture. In: Proceedings of the Third European Conference on Precision Agriculture, 18-20 June, Montpellier, France, European Commission Agenda 2000

van der Schilden M (2003). Future scenarios of agroentrepreneurship. In: Management and Technology Applications to Empower Agriculture and Agro-Food Systems: XXX CIOSTA-CIGR V Congress Proceedings (Piccarolo $\mathrm{P}$, ed), pp 3-14. Universita degli Studi di Torino, Turin, Italy 